\title{
Strength Assessment of Fly Ash Concrete with Water Containing Sodium Hydroxide
}

\author{
Prof. Jayeshkumar Pitroda, Dr. L.B.Zala, Dr.F.S.Umrigar \\ ${ }^{I}$ Assistant Professor \& Research Scholar, Civil Engg Department, B.V.M. Engineering College, Vallabh \\ Vidyanagar \\ ${ }^{2}$ Head \& professor, Civil Engineering Department, B.V.M. Engineering College, Vallabh Vidyanagar \\ ${ }_{3}^{3}$ Principal, B.V.M. Engineering College, Vallabh Vidyanagar - Gujarat -India
}

\begin{abstract}
This paper presents the effect of sodium hydroxide $(\mathrm{NaOH})$ present in the curing water on the strength of fly ash cement concrete. The concrete is produced by mixing of \% replacement of cement by fly ash and curing water containing $\mathrm{NaOH}$ of $5 \%$ concentration with constant dosages. This research work describes the feasibility of using the fly ash (Class-F) in concrete production as partial replacement of cement by weight. The cement has been replaced by fly ash accordingly in the range of $0 \%$ (without fly ash), 10\%, 20\%, 30\% and 40\% by weight of cement for M-40 mix. The compressive strengths were evaluated for 56 days of normal curing and 28 days normal +28 days $5 \% \mathrm{NaOH}$ contain water curing. The results show that, the compressive strength of fly ash cement concrete has come down with an increase in the \% replacement of cement by fly ash with constant dosages of $5 \%$ concentrated $\mathrm{NaOH}$ solution at 56 days. Compressive strengths of fly ash Cement Concrete have decreased in the range of 8.22 to $36.11 \%$, when compared with the control specimens. By using Regression Models we can predict the compressive strength value and the ratio with predicted values.
\end{abstract}

Keywords: - Fly Ash Cement Concrete, Compressive Strength, Regression Models, Sodium Hydroxide

\section{INTRODUCTION}

Concrete is the most widely consumed material in the world, after water. Nowadays, most of the construction of buildings and infrastructures are using concrete as a construction material. It is a construction material composed of cement as well as other cementations materials such as slag cement, aggregate, water, and chemical admixtures. Concrete solidifies and hardens after mixing with water and placement due to a chemical process known as hydration. The water reacts with the cement, which bonds the other components together, eventually creating a stone-like material. As it gives benefit to the construction field, it's also given environmental problem. The cement industry is one of the primary producers of carbon dioxide $\left(\mathrm{CO}_{2}\right)$, cement kiln $\mathrm{CO} 2$ is released from calcinations of limestone $( \pm 50 \%)$ and from the combustion of fuels $( \pm 50 \%)$, and cement production accounts for approximately $5 \%$ of the global $\mathrm{CO}_{2}$ emissions.

The durability of concrete can be defined as the ability to perform satisfactorily in the exposure condition to which it is subjected over an intended period of time with minimum of maintenance. Durability problems related to environmental causes include the following: steel corrosion, delamination, cracking, carbonation, sulfate attack, chemical attack, scaling, spalling, abrasion and cavitation.

Water is an important ingredient of concrete, which is not only actively participates in the hydration of cement but also contributes to the workability of fresh concrete and durability of hardened concrete. Cement is a mixture of complex compounds, the reaction of cement with water leads to setting and hardening. Since water helps to form the strength giving cement gel, the quality of water is to be critically monitored and controlled during the process of concrete making. In practice, very often, great control on the properties of cement and aggregate is exercised but the control on the quality of water is often neglected.

\section{MATERIALS AND METHODS}

\section{a) Supplementary Cementitious Material: Fly Ash}

Fly ash is composed of the non-combustible mineral portion of coal. Particles are glassy, spherical 'ball bearings' finer than cement particles. Sizes of particle are $0.1 \mu \mathrm{m}-150 \mu \mathrm{m}$. It is a pozzolonic material which reacts with the free lime in the presence of water, converted into calcium silicate hydrate $(\mathrm{C}-\mathrm{S}-\mathrm{H})$ which is the strongest and durable portion of the post in concrete. The fly ash is procured from Maize Products (A division of Sayaji Industries Ltd) Power plant. This plant is located near Kathwada in Ahmedabad District in Gujarat State.

\section{b) Ordinary Portland Cement}

The most common cement used is an Ordinary Portland Cement (OPC). The Ordinary Portland Cement of 53 grades conforming to IS:8112-1989 is used. Many tests were conducted on cement; some of 
them are specific gravity, consistency tests, setting time tests, compressive strengths, etc. The Physical properties of cement present in the cements are presented in Table 1.

TABLE 1 PROPERTIES OF ORDINARY PORTLAND CEMENT 53 GRADES

\begin{tabular}{|c|l|c|c|}
\hline $\begin{array}{c}\text { Sr. } \\
\text { No. }\end{array}$ & \multicolumn{1}{|c|}{ Physical properties of cement } & Result & $\begin{array}{c}\text { Requirements as per IS:8112- } \\
\mathbf{1 9 8 9}\end{array}$ \\
\hline 1 & Specific gravity & 3.15 & $3.10-3.15$ \\
\hline 2 & Standard consistency (\%) & $28 \%$ & $30-35$ \\
\hline 3 & Initial setting time (hours, $\min )$ & $35 \mathrm{~min}$ & $30 \mathrm{minimum}$ \\
\hline 4 & Final setting time (hours, $\min )$ & $178 \mathrm{~min}$ & $600 \mathrm{maximum}$ \\
\hline 5 & Compressive strength- 7 days & $38.49 \mathrm{~N} / \mathrm{mm}^{2}$ & $43 \mathrm{~N} / \mathrm{mm}^{2}$ \\
\hline 6 & Compressive strength- 28 days & $52.31 \mathrm{~N} / \mathrm{mm}^{2}$ & $53 \mathrm{~N} / \mathrm{mm}^{2}$ \\
\hline
\end{tabular}

Chemical Properties of Ordinary Portland Cement (OPC) and Fly Ash (F-Class) as listed in Table 2.

TABLE 2 CHEMICAL PROPERTIES OF OPC AND FLY ASH (F-CLASS)

\begin{tabular}{|c|c|c|}
\hline Chemical Properties & $\begin{array}{c}\text { Ordinary Portland Cement (OPC) } \\
\text { (Percent by mass) }\end{array}$ & $\begin{array}{c}\text { Fly Ash } \\
\text { (F-Class) } \\
\text { (Percent by mass) }\end{array}$ \\
\hline Silicon Dioxide (SiO2) & $21.77 \%$ & $62.22 \%$ \\
\hline Calcium Oxide $(\mathrm{CaO})$ & $57.02 \%$ & $5.30 \%$ \\
\hline Magnesium Oxide $(\mathrm{MgO})$ & $2.71 \%$ & $6.09 \%$ \\
\hline Sulphur Trioxide $(\mathrm{SO} 3)$ & $2.41 \%$ & $3.00 \%$ \\
\hline Aluminium Oxide $(\mathrm{Al} 2 \mathrm{O} 3)$ & $2.59 \%$ & $7.63 \%$ \\
\hline Ferric Oxide (Fe2O3) & $0.65 \%$ & $0.13 \%$ \\
\hline Loss on Ignition & $2.82 \%$ & $9.98 \%$ \\
\hline
\end{tabular}

c) Fine Aggregate

Those fractions from $4.75 \mathrm{~mm}$ to 150 microns are termed as fine aggregate. The river sand and crushed sand are used in combination as fine aggregate conforming to the requirements of IS: 383. The river sand is washed and screened, to eliminate deleterious materials and oversize particles.

\section{d) Coarse Aggregate}

The fractions from $20 \mathrm{~mm}$ to $4.75 \mathrm{~mm}$ are used as coarse aggregate. The Coarse Aggregates from crushed Basalt rock, conforming to IS: 383 are used. The Flakiness Index and Elongation Index were maintained well below $15 \%$.

e) Water

Curing water containing 5\% concentrated $\mathrm{NaOH}$ solution with constant dosages is used.

\section{DESIGN MIX METHODOLOGY}

a) Design Mix

A mix M40 grade were designed as per IS 10262:2009 and the same was used to prepare the test samples. The design mix proportion is shown in Table 3

TABLE 3 CONCRETE DESIGN MIX PROPORTIONS

\begin{tabular}{|c|c|c|c|c|c|c|}
\hline \multirow{2}{*}{$\begin{array}{c}\text { Sr. } \\
\text { No. }\end{array}$} & \multirow{2}{*}{$\begin{array}{c}\text { Mix } \\
\text { Mixete }\end{array}$} & \multicolumn{4}{|c|}{$\begin{array}{c}\text { Concrete Design Mix Proportion } \\
\text { (By Weight in kg) }\end{array}$} & $\begin{array}{c}\text { \% Replacement } \\
\text { of Cement by } \\
\text { Fly ash }\end{array}$ \\
\cline { 3 - 6 } & & $\begin{array}{c}\text { Water/Cement } \\
\text { Ratio }\end{array}$ & Cement & $\begin{array}{c}\text { Fine } \\
\text { Aggregate }\end{array}$ & $\begin{array}{c}\text { Coarse } \\
\text { Aggregate }\end{array}$ & \\
\hline 1 & A2 & 0.38 & 473.68 & 341.91 & 1419.30 & $0 \%(0 \mathrm{~kg})$ \\
\hline 2 & B5 & 0.38 & 426.31 & 341.91 & 1419.30 & $10 \%(47.37 \mathrm{~kg})$ \\
\hline 3 & B6 & 0.38 & 378.94 & 341.91 & 1419.30 & $20 \%(94.74 \mathrm{~kg})$ \\
\hline 4 & B7 & 0.38 & 331.58 & 341.91 & 1419.30 & $30 \%(142.10 \mathrm{~kg})$ \\
\hline 5 & B8 & 0.38 & 284.21 & 341.91 & 1419.30 & $40 \%(189.47 \mathrm{~kg})$ \\
\hline
\end{tabular}


Test samples are prepared with the range of $0 \%$ (without fly ash), 10\%, 20\%, 30\% and $40 \%$ by weight of cement for the M-40 mix.

\section{b) Alkali Attack Test}

This test was carried out on the specimens of $100 \mathrm{~mm}$ diameter and $200 \mathrm{~mm}$ height. Total 30 cylinders were cast and demoulded after 24 hours. 15 cylinders are tested at the ends of 56 days of the normal curing period. 15 cylinders are tested at the ends of 56 days ( 28 days normal +28 days $5 \% \mathrm{NaOH}$ contain) water curing period. The specimens were taken out from the curing tank and initial weight was taken.

The concentration of the solution was maintained throughout this period by changing the solution periodically. The surface of the cylinders was cleaned, weighed and then tested on the compressive testing machine under the uniform rate of loading of $120 \mathrm{~kg} / \mathrm{cm} 2 / \mathrm{min}$. The changes in strength of the concrete cylinders were calculated as per IS: 516-1959.

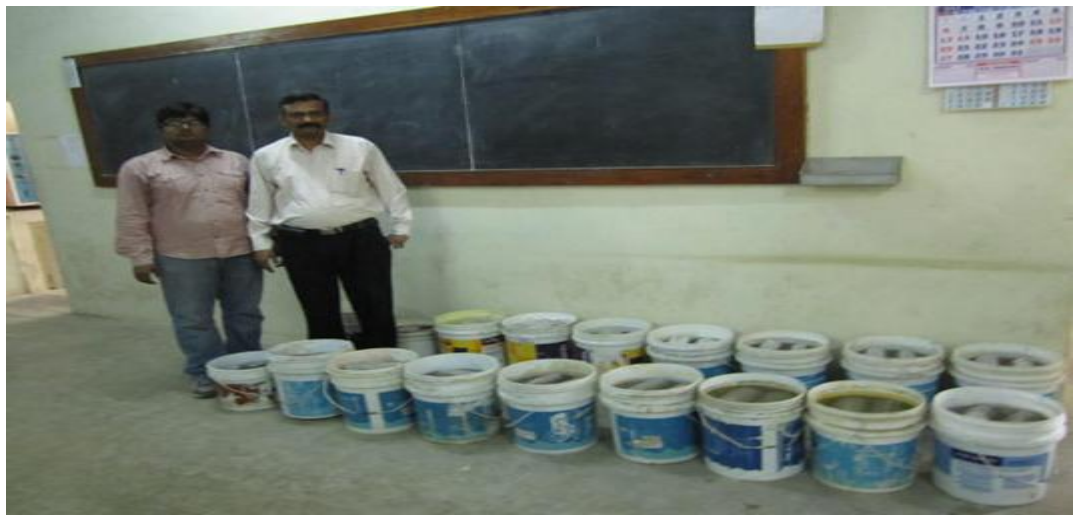

Figure: 1 Test Setup for Alkali Attack

\section{RESULTS AND DISCUSSION}

a) Effect on weight of Fly Ash Cement Concrete

The effect of $\mathrm{NaOH}$ on weight of fly ash cement concrete is shown in Table 4, from which it is observed that with increases in \% replacement of cement by fly ash, the \% loss in weight also increases.

TABLE 4 EFFECT ON WEIGHT OF FLY ASH CEMENT CONCRETE

\begin{tabular}{|c|c|c|c|c|c|}
\hline $\begin{array}{c}\text { Sr. } \\
\text { No. }\end{array}$ & $\begin{array}{c}\text { Concrete } \\
\text { Mix }\end{array}$ & $\begin{array}{c}\text { \% Replacement of } \\
\text { Cement by } \\
\text { Fly ash }\end{array}$ & $\begin{array}{c}\text { Oven Dry Weight in } \\
\text { Grams (W1) }\end{array}$ & $\begin{array}{c}\text { Wet Weight in } \\
\text { Grams (W2) }\end{array}$ & $\begin{array}{c}\text { Loss in } \\
\text { Weight \% } \\
\text { age }\end{array}$ \\
\hline 1 & A2 & $0 \%$ & 3.937 & 3.930 & -0.17 \\
\hline 2 & B5 & $10 \%$ & 3.648 & 3.641 & -0.19 \\
\hline 3 & B6 & $20 \%$ & 3.603 & 3.595 & -0.20 \\
\hline 4 & B7 & $30 \%$ & 3.623 & 3.614 & -0.24 \\
\hline 5 & B8 & $40 \%$ & 3.645 & 3.635 & -0.27 \\
\hline
\end{tabular}

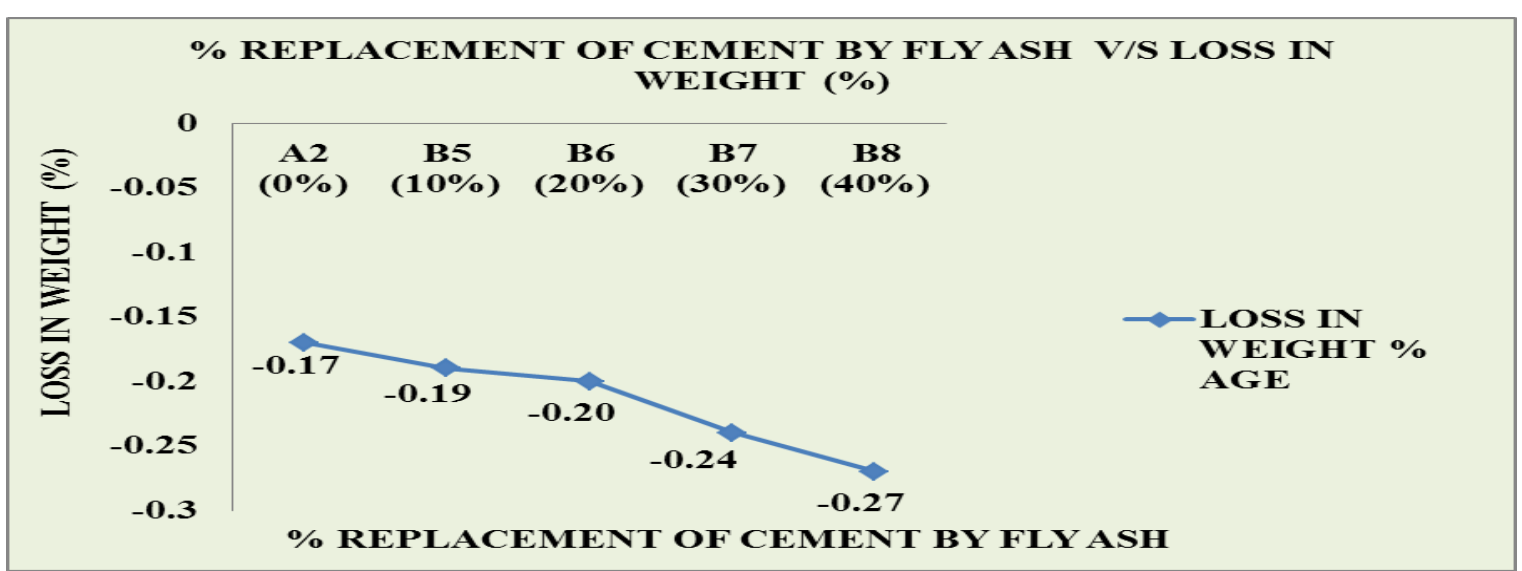

Figure: 2 \% Replacement of Cement by Fly Ash v/s Loss in Weight (\%) 
b) Effect on Compressive Strength of Fly Ash Cement Concrete

The effect of $\mathrm{NaOH}$ concentration on the compressive strength Fly Ash Cement Concrete is presented in Table 5 .

TABLE 5 Compressive Strength of Fly Ash Cement Concrete Corresponding To Naoh Contain Curing

\begin{tabular}{|c|c|c|c|c|c|c|c|}
\hline \multirow[t]{3}{*}{$\begin{array}{l}\text { Sr. } \\
\text { No }\end{array}$} & \multirow[t]{3}{*}{$\begin{array}{c}\text { Concrete } \\
\text { Mix }\end{array}$} & \multirow{3}{*}{$\begin{array}{c}\% \\
\text { Replacement } \\
\text { of } \\
\text { Cement by } \\
\text { Fly ash }\end{array}$} & \multicolumn{3}{|c|}{ Fly Ash Cement Concrete } & \multicolumn{2}{|c|}{$\begin{array}{c}\% \text { Change in Compressive } \\
\text { Strength }\end{array}$} \\
\hline & & & $\begin{array}{l}\text { Compressive } \\
\text { Strength } \\
\mathrm{N} / \mathrm{mm}^{2}(\mathrm{Pl}) \\
100 \mathrm{X} 200\end{array}$ & $\begin{array}{c}\text { Compressive } \\
\text { Strength N/mm } \\
\text { (P2) } \\
100 \text { X200 }\end{array}$ & $\begin{array}{c}\text { Loss in } \\
\text { Compressive } \\
\text { Strength } \% \\
\text { age }(\mathrm{P} 2-\mathrm{Pl} / \mathrm{Pl})\end{array}$ & $\begin{array}{l}\text { Compressive } \\
\text { Strength } \\
\mathrm{N} / \mathrm{mm}^{2}(\mathrm{Pl}) \\
100 \mathrm{X} 200\end{array}$ & $\begin{array}{l}\text { Compressive } \\
\text { Strength } \\
\mathrm{N} / \mathrm{mm}^{2}(\mathrm{P} 2) \\
100 \mathrm{X} 200\end{array}$ \\
\hline & & & $\begin{array}{c}\text { With normal } \\
\text { curing of } 56 \\
\text { days }\end{array}$ & $\begin{array}{l}\text { With } 28 \text { days } \\
\text { normal curing } \\
\text { and } 28 \text { days } \\
\mathrm{NaOH} \text { contain } \\
\text { curing }\end{array}$ & & $\begin{array}{c}\text { With normal } \\
\text { curing of } \mathbf{5 6} \\
\text { days }\end{array}$ & $\begin{array}{l}\text { With } 28 \text { days } \\
\text { normal curing } \\
\text { and } 28 \text { days } \\
\text { NaOH contain } \\
\text { curing }\end{array}$ \\
\hline 1 & A2 & $0 \%$ & 31.00 & 30.57 & -1.39 & 0 & 0 \\
\hline 2 & B5 & $10 \%$ & 33.55 & 27.18 & -18.99 & 8.22 & -11.08 \\
\hline 3 & B6 & $20 \%$ & 30.57 & 26.33 & -13.87 & -1.38 & -13.86 \\
\hline 4 & B7 & $30 \%$ & 28.87 & 20.38 & -29.41 & -6.87 & -33.33 \\
\hline 5 & B8 & $40 \%$ & 27.18 & 19.53 & -28.15 & -12.32 & -36.11 \\
\hline
\end{tabular}

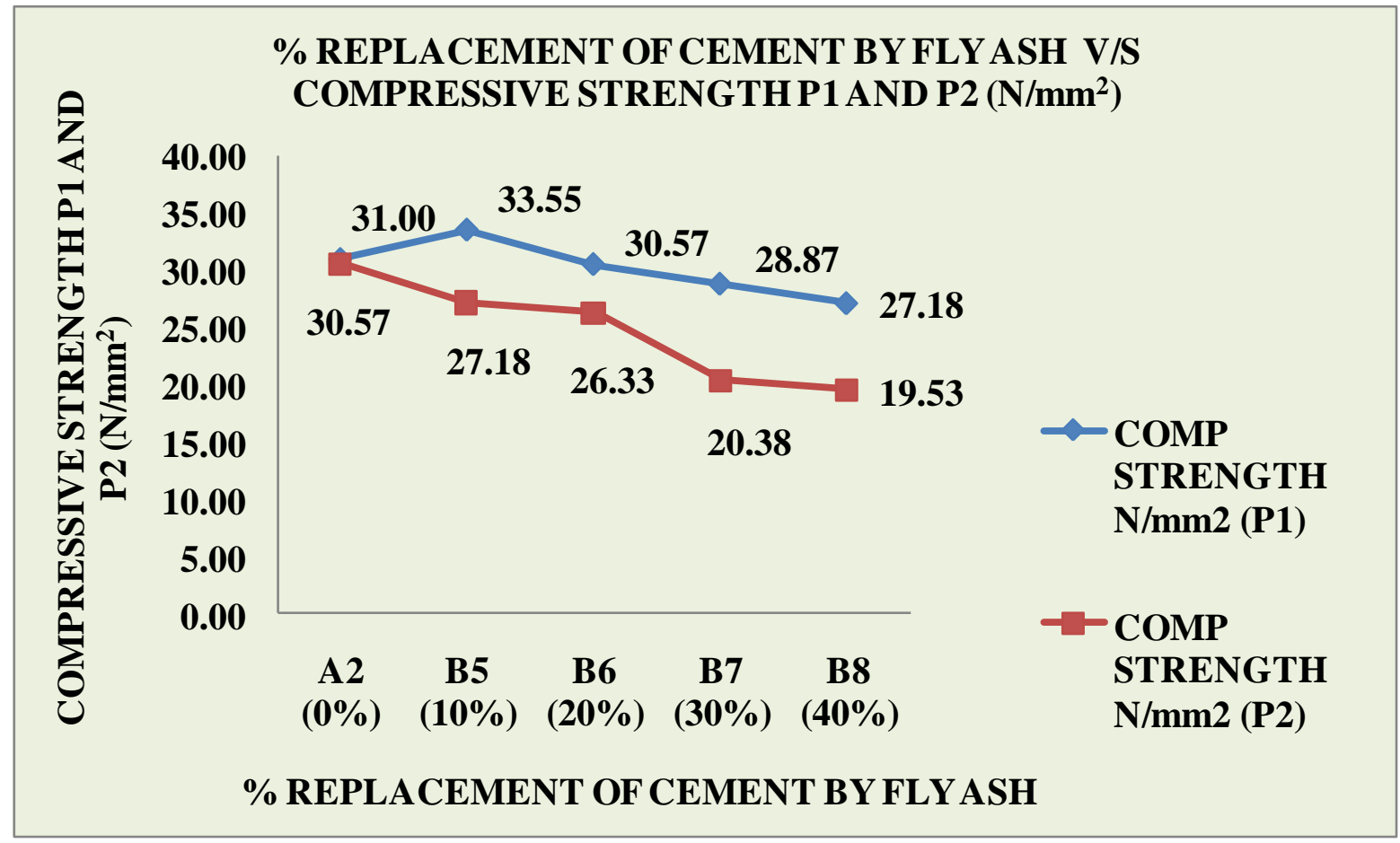

Figure: 3 \% Replacement of Cement by Fly Ash V/S Compressive Strength (N/mm²) P1 and P2

Decrease in compressive strength of specimens cured with $\mathrm{NaOH}$ solution is observed. The rate of decrease in compressive strength also gradually increases with an increase in the $\%$ of fly ash in the concrete. With the \% replacement of cement by fly ash $0 \%, 10 \%, 20 \%, 30 \%$ and $40 \%$ with normal curing after 56 days the compressive strength of cylinders is decreased but parallel the compressive strength with 56 days (28 days normal +28 days $5 \% \mathrm{NaOH}$ contain) curing also deceased. The decrease in compressive strength is $36.11 \%$ for 56 day concrete

It was also observed that the fly ash cement concrete shown a noteworthy resistance vis-a-vis the plain concrete. Similar observations were also noticed in the present experimental investigation.

\section{c) REGRESSION MODELS}

To estimate the compressive strength of fly ash cement concrete exposed to $\mathrm{NaOH}$, two regression models have been developed one each for 56 days M40. The regression models are given below. 
$\mathrm{fck} 56_{1}=32.698-0.1232 \times \mathrm{C}$

Equation (1)

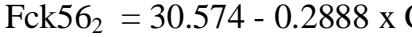

Equation (2)

Where,

$\mathrm{f}_{\mathrm{ck}} 56_{1}=$ Compressive strength of Fly Ash Concrete in N/mm ${ }^{2}$ with normal curing of 56 days

$\mathrm{F}_{\mathrm{ck}} 56_{2}=$ Compressive strength of Fly Ash Concrete in $\mathrm{N} / \mathrm{mm}^{2}$ with 28 days curing +28 days $5 \% \mathrm{NaOH}$ contain curing

$\mathrm{C}=\%$ replacement of cement by fly ash

The coefficient of co-relation factor for regression equations 1 and 2 is $\mathbf{0 . 6 6 3 3}$ and $\mathbf{0 . 9 4 1 3}$ respectively. The performance of regression models is presented in Table 6.

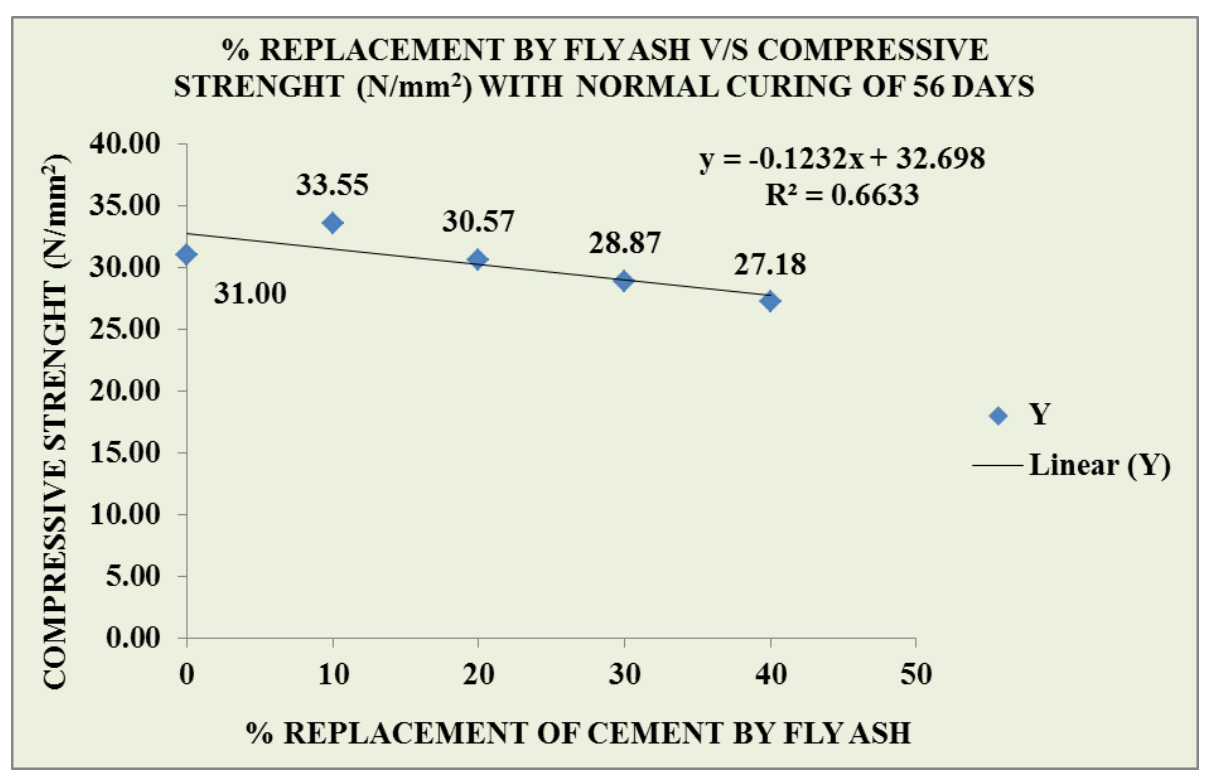

Figure: $4 \%$ Replacement of Cement by Fly Ash V/S Compressive Strength $\left(\mathrm{N} / \mathrm{mm}^{2}\right)$ Normal Curing of 56 Days

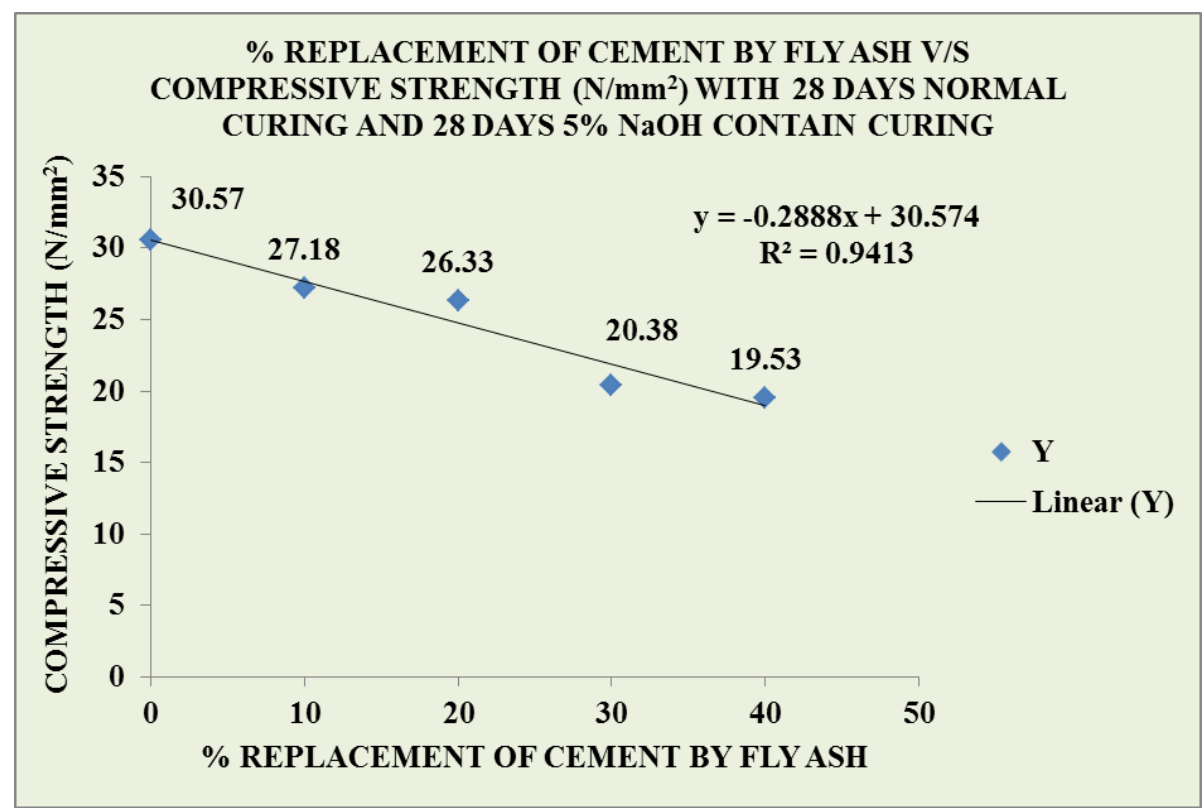

Figure: $5 \%$ Replacement of Cement by Fly Ash V/S Compressive Strength $\left(\mathrm{N} / \mathrm{mm}^{2}\right)$ with 28 Days Normal Curing and 28 Days $5 \% \mathrm{NaOH}$ Contain Curing 
TABLE 6 PERFORMANCE OF REGRESSION MODELS FOR COMPRESSIVE STRENGTH

\begin{tabular}{|c|c|c|c|c|c|c|c|}
\hline \multirow[t]{2}{*}{$\begin{array}{l}\text { Sr. } \\
\text { No. }\end{array}$} & \multirow{2}{*}{$\begin{array}{c}\% \\
\text { Replacement of } \\
\text { Cement by } \\
\text { Fly ash }\end{array}$} & \multicolumn{3}{|c|}{$\begin{array}{l}\text { Compressive Strength of Fly Ash } \\
\text { Concrete in Mpa with Normal Curing of } \\
56 \text { days }\end{array}$} & \multicolumn{3}{|c|}{$\begin{array}{l}\text { Compressive Strength of Fly Ash Concrete } \\
\text { in } \mathrm{MPa} \text { with } 28 \text { days Normal Curing and } 28 \\
\text { days } \mathrm{NaOH} \text { Solution Curing }\end{array}$} \\
\hline & & $\begin{array}{c}\text { Experimental } \\
\text { (EXP) }\end{array}$ & $\begin{array}{c}\text { Regression } \\
\text { Model (RM) }\end{array}$ & $\begin{array}{l}\text { R.M./ } \\
\text { EXP }\end{array}$ & $\begin{array}{c}\text { Experimental } \\
\text { (EXP) }\end{array}$ & $\begin{array}{c}\text { Regression } \\
\text { Model (RM) }\end{array}$ & $\begin{array}{l}\text { R.M./ } \\
\text { EXP }\end{array}$ \\
\hline 1 & $0 \%$ & 28.03 & 32.70 & 1.05 & 25.05 & 30.57 & 1.00 \\
\hline 2 & $10 \%$ & 27.18 & 31.47 & 0.94 & 24.20 & 27.69 & 1.02 \\
\hline 3 & $20 \%$ & 25.90 & 30.23 & 0.99 & 20.81 & 24.80 & 0.94 \\
\hline 4 & $30 \%$ & 23.35 & 29.00 & 1.00 & 17.41 & 21.91 & 1.08 \\
\hline 5 & $40 \%$ & 20.81 & 27.77 & 1.02 & 16.56 & 19.02 & 0.97 \\
\hline
\end{tabular}

From this table the ratios between experimental compressive strength value and the value predicted by the regression model for with normal curing of 56 days are about 0.94 to 1.05 and with 28 days normal curing and 28 days $5 \% \mathrm{NaOH}$ solution curing are about 0.94 to 1.08 respectively. This implies the proposed models made a good agreement with experimental values.

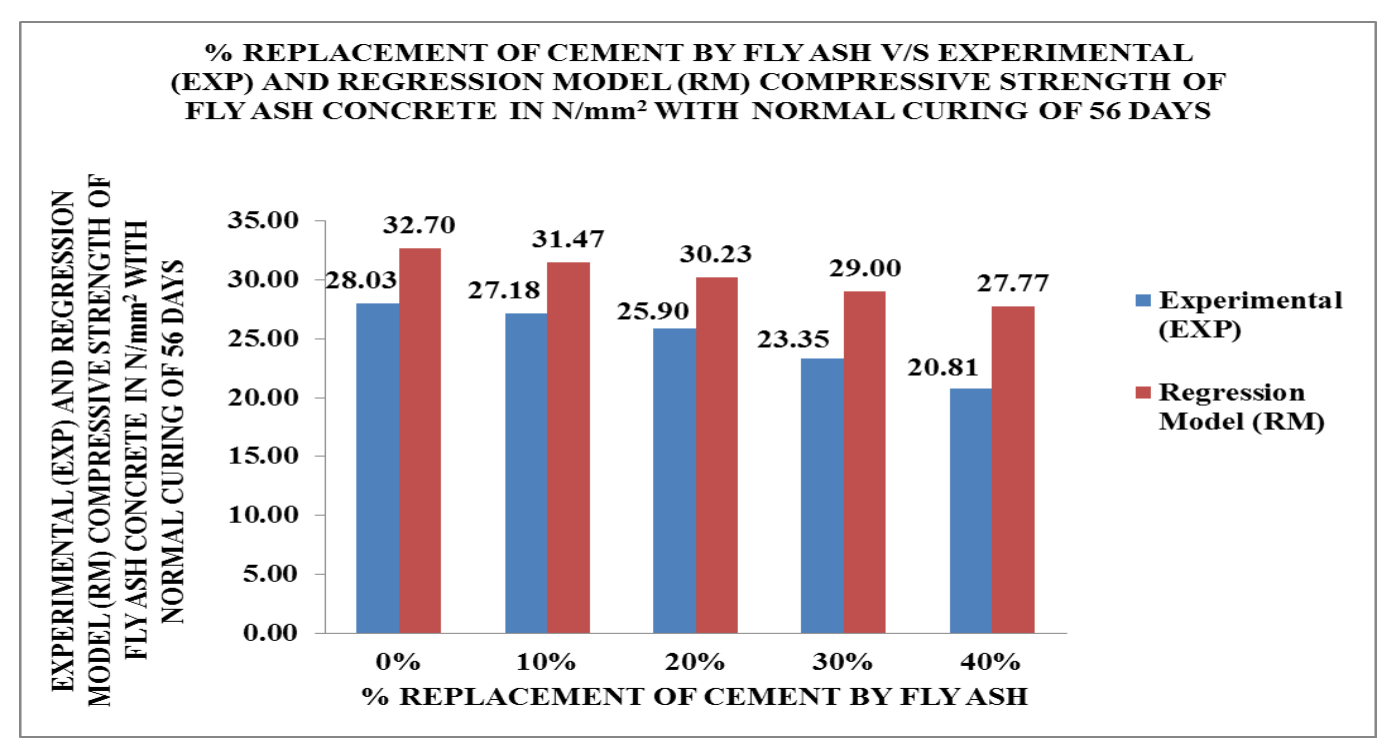

Figure: 6 \% Replacement of Cement by Fly Ash V/S Experimental (EXP) and Regression Model (RM) Compressive Strength of Fly Ash Concrete in N/mm² with Normal Curing of 56 Days

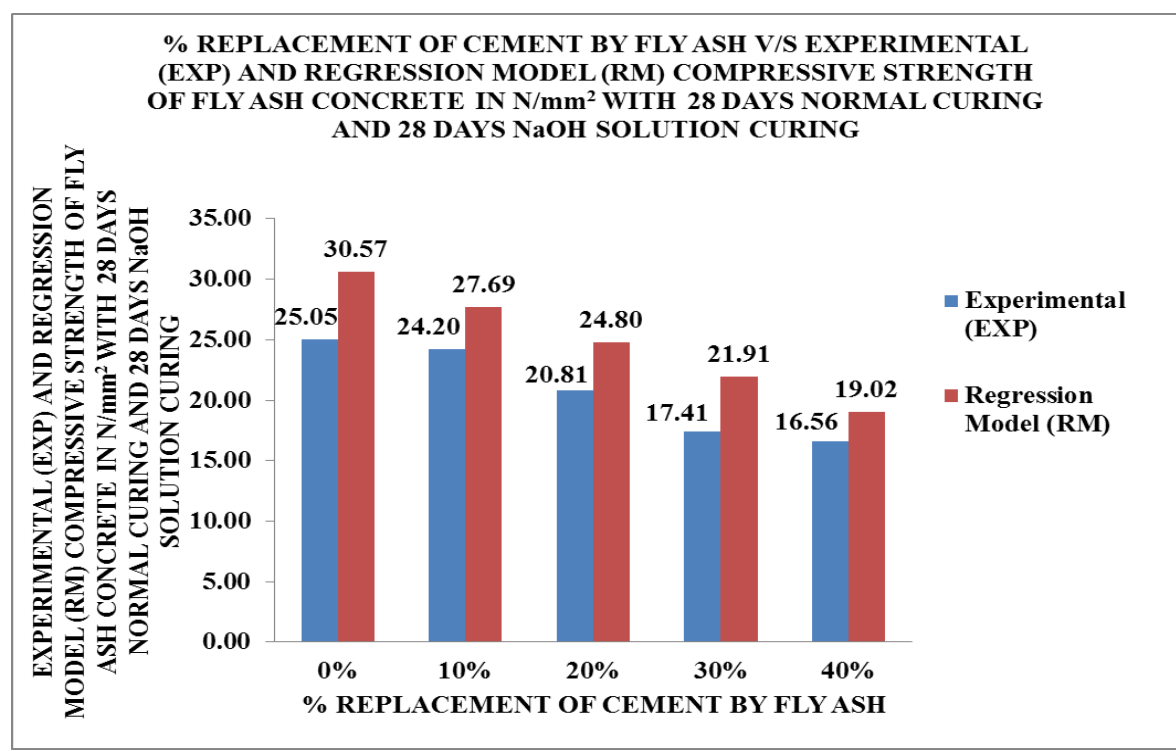

Figure: 7 \% Replacement of Cement by Fly Ash V/S Experimental (EXP) and Regression Model (RM) Compressive Strength of Fly Ash Concrete in N/mm with 28 days Normal Curing and 28 Days NaOH Solution Curing 


\section{CONCLUSIONS}

The following conclusions were made from the experimental work.

1. Continuous loss in weight fly ash cement concrete specimens prepared with $0 \%$ to $40 \%$ replacement of fly ash by $0.17 \%$ to $0.27 \%$.

2. Continuous decrease in compressive strength of fly ash cement concrete specimens prepared with $0 \%$ to $40 \%$ replacement of cement by fly ash when cured by $\% \mathrm{NaOH}$ contain solution is $1.39 \%$ to $29.41 \%$.

3. The proposed regression models shown good performance to predict the compressive strength.

\section{ACKNOWLEDGEMENT}

The Authors thankfully acknowledge to Dr. C. L. Patel, Chairman, Charutar Vidya Mandal, Er.V.M.Patel, Hon. Jt. Secretary, Charutar Vidya Mandal, Mr. Yatinbhai Desai, Jay Maharaj construction, Prof. J. J. Bhavsar, PG coordinator of Construction Engineering \& Management, BVM Engineering College, Vallabh Vidyanagar, Gujarat, India for their motivations and infrastructural support to carry out this research.

\section{REFERENCES}

[1] Abbas S. Al-Ameeri, K.A.Al- Hussain and M.S Essa, "Constructing a Mathematical Models to Predict Compressive Strength of Concrete from Non-Destructive Testing", International Journal of Civil Engineering \& Technology (IJCIET), Volume 4, Issue 4, 2013, pp. 1 - 20, ISSN Print: 0976 - 6308, ISSN Online: 0976 - 6316.

[2] Alaa Abdul Kareem Ahmad, "The Effect of Gypsum Compensative on Mortar Compressive Strength", International Journal of Civil Engineering \& Technology (IJCIET), Volume 4, Issue 3, 2013, pp. 168 175, ISSN Print: 0976 - 6308, ISSN Online: 0976 - 6316.

[3] Behrouz Mohebimoghaddam and S.Hossein Dianat, "Evaluation of the Corrosion and Strength of Concrete Exposed to Sulfate Solution", International Journal of Civil Engineering \& Technology (IJCIET), Volume 3, Issue 2, 2012, pp. 198 - 206, ISSN Print: 0976 - 6308, ISSN Online: 0976 - 6316.

[4] F. Pacheco-Torgal and Said Jalali, Sulphuric acid resistance of plain, polymer modified, and fly ash cement concretes, Construction and Building Materials, 23, 2009, 3485-3491.

[5] H. Sudarsana Rao, Vaishali.G.Ghorpade, "strength assessment of blended cement concrete with water containing sulphuric acid", International Journal of Civil Engineering and Technology (IJCIET), ISSN 0976 - 6308 (Print), ISSN 0976 - 6316(Online) Volume 4, Issue 5, September - October (2013), () IAEME, pp. 9 - 14

[6] J. P. Gorninski, D. C. Dal Molin and C. S. Kazmierczak, Strength degradation of polymer concrete in acidic environments, Cement and Concrete Composites, 29 (8), 2007, 637-645.

[7] Jayeshkumar Pitroda, Dr. F S Umrigar (2013), "Evaluation of Sorptivity and Water Absorption of Concrete with Partial Replacement of Cement by Thermal Industry Waste (Fly Ash)" International Journal of Engineering and Innovative Technology (IJEIT) Volume 2, Issue 7, January 2013, ISSN: 2277-3754, ISO 9001:2008 Certified, pp-245-249.

[8] Jayeshkumar Pitroda, Dr. L. B. Zala, Dr. F. S. Umrigar (2012), "Experimental Investigations on Partial Replacement of Cement with Fly Ash in Design Mix Concrete" International Journal of Advanced Engineering Technology, IJAET/Vol. III/ Issue IV/Oct. -Dec., 2012/126-129

[9] Jayraj Vinodsinh Solanki, Ronak Prakashkumar Patel, Prof. Jayeshkumar Pitroda (2013), "A Study on Low Quality Fly Ash as an Opportunity for Sustainable and Economical Concrete" IJSR - International Journal Of Scientific Research, Volume 2 Issue 2 Feb 2013 • ISSN No 2277 - 8179/ 116-118

[10] Rushabh A. Shah, Jayeshkumar R. Pitroda (2013), "Assessment of sorptivity and water absorption of mortar With the partial replacement of cement by fly ash (class-f)" International Journal of Civil Engineering and Technology (IJCIET), Volume 4, Issue 5, September - October, pp. 15-21, Journal Impact Factor (2013): 5.3277

[11] T. Fikret, A. Fevziye, K. Sema and Y. Nabi, Effects of magnesium sulfate concentration on the sulfate resistance of mortars with and without silica fume, Cement and Concrete Research, 27 (2), 1997, 205-214

[12] V. Venkateswara Reddy, H. Sudarsana Rao and K. N. Jayaveera, Influence of strong alkaline substances (sodium carbonate and sodium bicarbonate) in mixing water on strength and setting properties of concrete, Indian Journal of Engineering and Material Sciences, 13(2), 2006, 123- 128.

[13] W. Kejin, E. N. Daniel, and A. N. Wilfrid, "Damaging effects of deicing chemicals on concrete materials, Cement and Concrete Composites", 28 (2), 2006, 173-178. 

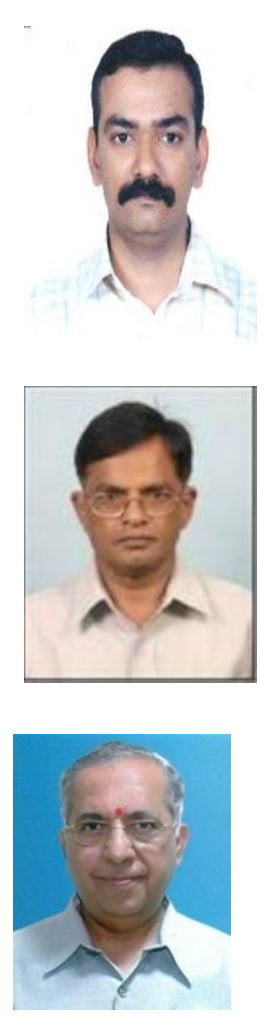

\section{AUTHOR'S BIOGRAPHY}

Prof. Jayeshkumar R. Pitroda was born in 1977 in Vadodara City. He received his Bachelor of Engineering degree in Civil Engineering from the Birla Vishvakarma Mahavidyalaya, Sardar Patel University in 2000. In 2009 he received his Master's Degree in Construction Engineering and Management from Birla Vishvakarma Mahavidyalaya, Sardar Patel University. He joined Birla Vishvakarma Mahavidyalaya Engineering College as a faculty where he is Assistant Professor of Civil Engineering Department with a total experience of 12 years in the field of Research, Designing and education. He is guiding M.E. (Construction Engineering \& Management) Thesis work in the field of Civil/ Construction Engineering. He has published papers in National Conferences and International Journals.

Dr.L.B.Zala completed his B.E. (Civil) Engineering from BVM Engineering College, S.P. University in 1984, M.E. (Civil) Transportation Engineering from University of Roorkee (now IIT, Roorkee) in 1994. Dr. Zala joined the BVM Engineering College as Assistant Lecture in August 1986. He completed his Ph.D in Civil Engineering from S.P. University in 2009. He is working as a Head Civil Engineering at BVM Engineering College. He is guiding M.E. / M. Tech \& Ph.D Dissertation work in field of Civil/Transportation Engineering.

Dr. Farokh Sorabji Umrigar completed his B.E. (Civil) Engineering from SVNIT in 1976, M.Tech. (Civil) Transportation System Engineering from IIT, Kanpur in 1982 and Ph.D with specialization in Transportation Engineering from University of Roorkee, Roorkee in 1990. Dr. Umrigar joined Birla Vishvakarma Mahavidyalaya Engineering College (BVM) in 1978 as an Assistant Lecturer and reached to the position of Principal of BVM in April, 2002 with a total experience of 34 years in the field of Research, Designing, education and administration. Dr. Umrigar is also Dean, Faculty of Engineering \& Technology, Sardar Patel University since April, 2002. Dr. Umrigar has published many papers at National and International level. He is an author of two books of civil engineering. He has guided many students at the master's and Ph.D level in the field of civil and transportation planning. 